Kádár, Judit. "Two Austro-Hungarian Women Writers, Anna Tutsek and Terka Lux, Creating New Urban Identities in Early Twentieth-Century Budapest." Hungarian Cultural Studies. e-Journal of the American Hungarian Educators Association, Volume 8 (2015): http://ahea.pitt.edu DOI: 10.5195/ahea.2015.214

\title{
Two Austro-Hungarian Women Writers, Anna Tutsek and Terka Lux, Creating New Urban Identities in Early Twentieth-Century Budapest
}

\author{
Judit Kádár
}

\begin{abstract}
In this paper, I examine some literary texts of two turn-of-the century Hungarian women writers, Anna Tutsek and Terka Lux, who left behind their childhood environment in remote regions of the Austro-Hungarian Monarchy in order to move to Budapest, the capital of the eastern part of the Empire. Assuming that individuals hold multiple identities that are flexible and inevitably affected by environmental and social changes, my main focus is on the transformation of their ethnic, regional, occupational, and gender identity influenced by the disengagement from their birthplace. Within a context of Hungarian-Eastern-European women's social history, I investigate how migration had led them to reshape their original identities and create new ones and how these emigrant writers reacted to the loss of cultural and social norms in which they had previously lived.
\end{abstract}

Keywords: Women Writers, Women's Social History, Anti-Semitism, Austro-Hungarian Monarchy, Transylvania, Partium

Biography: Judit Kádár, who received her Ph.D. in Hungarian Literature from the Hungarian Academy of Sciences, Budapest, teaches American Literature and Twentieth-Century British Prose in the English Department of the University of West-Hungary in Szombathely. Her main field of research is nineteenth and twentieth century Hungarian women writers, and she has published an anthology of twentieth century Hungarian women poets, Térdig születésben, halálban ['Up to Their Knees with Birth and Death'], a collection of literary criticism, Royal Flush. Kritikák a brit és amerikai prózairodalomról ['Royal Flush: Critical Essays on British and American Works of Prose'], and a monograph on preWorld War II Hungarian women writers Engedelmes lázadók ['Obedient Rebels'].

In this paper, I examine some literary texts of two turn-of-the century Hungarian women writers, Anna Tutsek and Terka Lux, who were pioneers of women's literature in the eastern part of the Austro-Hungarian Monarchy where the relatively long period of economic prosperity after 1867 brought about the birth of modern literature. Contrary to expectations, the first female writers of the era in Hungary did not belong to the new class of bourgeoisie but rather the majority of them descended from impoverished small-town noble or middle-class families that had been unable to adapt to the harsh conditions of industrial capitalism. Many of these young women left behind their childhood environment in remote regions of the empire to earn a living by writing and by editorial work in the Hungarian capital city. 
Kádár, Judit. "Two Austro-Hungarian Women Writers, Anna Tutsek and Terka Lux, Creating New Urban Identities in Early Twentieth-Century Budapest." Hungarian Cultural Studies. e-Journal of the American Hungarian Educators Association, Volume 8 (2015): http://ahea.pitt.edu DOI: 10.5195/ahea.2015.214

Assuming that individuals hold multiple identities, and accepting new research results which suggest that "the dominant cultural forces for most people seem to have been originally local and regional" (Straubhaar 2008: 14), it seems obvious that, besides their occupational and female identities, the disengagement from their birthplace affected the writer's regional and ethnic identities as well. By analyzing the writings of Tutsek and Lux, the aim of this paper on Hungarian-Eastern-European women's social history is to examine how migration had led them to reshape their original identities and create new ones and how these emigrant writers reacted to the loss of cultural and social norms in which they had previously lived.

\section{Anna Tutsek (1865-1944)}

I will focus on Tutsek's memoir, Az én utam ['My Way,' 1935] to prove that the function of its insincere utterances and secretiveness was to obscure her past history and to demonstrate the validity of her new identities. In this autobiographical book, she described the circumstances under which she had gone forth from her Transylvanian birthplace Kolozsvár [Cluj-Napoca, Klausenburg] to seek employment in the Hungarian capital where she made a successful career in journalism and writing novels. Her memoir, published at the age of seventy, chronicles her youth in Kolozsvár and her debut as an editor in Budapest. It seems to be full of nostalgia for the early years of her happy childhood in the one-time cultural capital of Transylvania. At the same time, her depiction of the family's miserable life after her father's death in Kolozsvár and later in Budapest, where she migrated with her mother, reflects obedience and humility; this reveals a hidden ambivalence towards her childhood and her adolescence.

Throughout her memoir Tutsek attempts to conceal some important facts, which helped strengthen the new identities she had created by the 1930s. First of all, in Az én utam, although her mother's older brother, whom she identifies only as "Uncle Sándor," and who was a wealthy linseed oil factory owner who took care of the large family, is a central figure in her reminiscences, yet she never once revealed the surname of the maternal line. Even while Tutsek's father was still alive it is this "Uncle Sándor" who was the pater familias who by the power of his wealth exercised dominating influence not only over the life of his widowed or never-married sisters, but also his married sister, her husband and their children, including Anna. When the family gathered on Sundays in Uncle Sándor's eight-room home in the center of town, everybody was expected to speak German; perhaps the mother's side of the family was German or Transylvanian Saxon in origin (three of the eleven siblings had been living in Vienna), and maybe Tutsek wanted to keep their foreign descent secret in a period when the change of foreign surnames to Hungarian sounding ones was in fashion (see Nemes on showing patriotism by adopting Hungarian-sounding names started during the Hungarian revolution in 1848, 2005: 41). Yet, Tutsek, while concealing the possible German ethnicity of the maternal side of her family, was proud of her knowledge of German culture, noting with satisfaction that as a teenager she used to read Goethe, Schiller, Heine, and Lessing in the original. Yet, this would not necessarily imply a German background, because the education of the Hungarian elite had long been based on German culture and this remained the same until the outbreak of World War II.

Tutsek not only was hazy about her mother's probable German or Saxon ancestry but also hid her father's Armenian descent, and hence her own, on more than one occasion in her memoir. Tutsek is a common Armenian surname in Transylvania; however, it is likely that her great-grandfather had assimilated into Hungarian culture, and she had only scant knowledge of Armenian traditions. Significantly, when in the middle 1870s she visited her father's birthplace, Torockó [Râmetea, Eisenburg], the little Anna was most impressed by the gold and silver threads 
Kádár, Judit. "Two Austro-Hungarian Women Writers, Anna Tutsek and Terka Lux, Creating New Urban Identities in Early Twentieth-Century Budapest." Hungarian Cultural Studies. e-Journal of the American Hungarian Educators Association, Volume 8 (2015): http://ahea.pitt.edu DOI: 10.5195/ahea.2015.214

woven into the shoulder corsets and headdresses of the Szekler brides' traditional costume. From an Armenian perspective she was enthusiastic about the wrong thing, for the use of goldwork embroidery had been prohibited by the leaders of Armenian communities in Transylvania already in the eighteenth century in order to prevent social tensions (Dzsotjanne Krajcsir). As a little girl she might have been ignorant about her Armenian origins, but by the age of seventy she must have known about her roots, therefore her secrecy was obviously intentional. In the same memoir she remarked that her paternal aunt married an Armenian man, but she neglected to add that her aunt was Armenian as well. Praising the achievements of the short story writer István Petelei, a reviver of the cultural life in Kolozsvár and a supporter of the young Tutsek's literary ambitions, she concealed his Armenian origins also.

During Tutsek's childhood, Uncle Sándor, who was the godfather of all the children in the family, pressed Anna to cultivate the German language, while at the same time her parents made her assimilate to the Hungarian culture that had become dominant in Transylvania. When she migrated to Budapest, Anna Tutsek deliberately chose a purely Hungarian identity. It is true that considering her livelihood, she did not have a choice, because as Péter Hanák put it, "by the turn of the century, Hungarian identity had become an essential condition of getting ahead [in Hungary], it had become an article of faith of a 'national religion' and at the same time the basic condition of social integration" [A századvégre a magyar identitás létevidenciává, a "nemzetvallás"hittételévé s egyúttal a társadalmi integráció alapfeltételévé vált] (Hanák 1988: 136). ${ }^{1}$

Writing about her life at age seventy, in her memoir Tutsek not only obscured the ethnic identity of both sides of her family but also lied about her true age in the course of describing the events of her youth. For example, she never specified either the date of her father's death or the time of the sudden and supposedly unforeseen cancellation of Uncle Sándor's financial assistance to the whole Tutsek family. And it has therefore remained unclear how old she was when the family was financially ruined, when she gained her qualification as a booking clerk at the Hungarian State Railways, or how old she was when she and her mother ran away to Budapest. Her reticence in revealing her age was because when she and her mother arrived in the capital she would have been considered an old maid and not the young, independent woman she wanted to present herself as to her readers. In fact, in a society where the average age of marriage for girls was seventeen, even in Kolozsvár she had been considered a bluestocking and was advised by her family to give up reading and writing and to find a husband instead. After her sister had got married, Anna was invited to live as a spinster relative in her brother-in-law's household at Sepsiköröspatak [Valea Crișului], a remote village at the southeastern border of Austria-Hungary, but she despairingly rejected the idea. According to her memoir she immediately protested, saying "I don't want to live off my brother-in-law's beneficence!" $[A$ sógorom kegyelemkenyerén nem akarok élni] (Tutsek 1935:184).

\footnotetext{
${ }^{1}$ All translations from Hungarian are my own.
} 
Kádár, Judit. "Two Austro-Hungarian Women Writers, Anna Tutsek and Terka Lux, Creating New Urban Identities in Early Twentieth-Century Budapest." Hungarian Cultural Studies. e-Journal of the American Hungarian Educators Association, Volume 8 (2015): http://ahea.pitt.edu DOI: 10.5195/ahea.2015.214

Although Anna's short stories had been published in Hungarian literary magazines from the time she was fourteen or fifteen years old, and she also had articles published in the Germanlanguage Pester Lloyd likewise published in the capital city, she could not qualify as a primary school teacher, because she lacked formal qualifications. Thus the only career acceptable for a middle class woman was closed to her. At the same time, she was also not able to make a living with her writing because of the rigid male-centered social circles which gave scant opportunities for female writers, and even less so to an adolescent who was writing about topics like death and aging. She fled from Transylvania because the social norms were more backward, feudal, and at the same time more patriarchal than in the second capital of the Monarchy. In her memoir she reflected on the feudal traits of one-time Kolozsvár:

Besides, social life was rather fragmented. Not even Petelei's enormous efforts could dissipate the "caste system".... Not even art could merge the separate social classes. The families of university professors did not converse with the officials, the county and municipal officials held themselves aloof from the tradesmen, the tradesmen held themselves aloof from the craftsmen and so on (Tutsek 1935: 119-120).

[A társadalmi élet különben meglehetösen széttagolt volt. A szokásos vidéki szigorú "kasztrendszert" még Petelei minden fáradozásának sem sikerült eloszlatni .... De még a müvészet sem tudta összeolvasztani a társadalmilag elkülönített osztályokat. Az egyetemi tanárok családjai nem érintkeztek a hivatalnokokkal, a vármegyei és városi tisztviselök távoltartották magukat a kereskedöktöl, a kereskedök az iparosoktól - és így tovább.]

In Budapest, Tutsek and her mother rented a three-room flat in a modest neighborhood and sublet one of the rooms to young men to cover the rental cost of their new home. Anna earned money to pay for other expenses by writing articles to magazines until the sudden death of Mrs. Tutsek. Following her mother's passing away, as a relatively young middle-class woman Tutsek was not allowed to live in the same flat with unrelated men so she had no choice but to rent a cheap tenement room all alone. She did not reveal the date of her mother's death or the length of time she was living in misery, but she described her circumstances:

I became more and more dissatisfied with my little back-room on the fourth floor of a József Boulevard tenement. All noise penetrated from the kitchen, the constant smell of food swelled my nostrils, when I opened the window even worse smells and noises poured in. In winter I felt frozen to the very bowels, in summer the air was stifling, the heat was ferocious (Tutsek 1935: 206).

[Az én kis udvari szobám a József-körút negyedik emeletén mind kellemetlenebb lett nekem. A konyhából minden behallatszott, az állandó ételszag csavarta az orromat, ha szellöztettem, a folyosóról még rosszabb szagok és zajok áradtak be, télen olyan hideg volt, hogy majd megfagytam, nyáron meg elviselhetetlen, fullasztó volt a höség.] 
Kádár, Judit. "Two Austro-Hungarian Women Writers, Anna Tutsek and Terka Lux, Creating New Urban Identities in Early Twentieth-Century Budapest." Hungarian Cultural Studies. e-Journal of the American Hungarian Educators Association, Volume 8 (2015): http://ahea.pitt.edu DOI: 10.5195/ahea.2015.214

Anna was still living in a tenement room without regular income when she was offered the position of editor-in-chief of a new magazine for teenage girls by one of the largest and most successful of Hungarian publishers. The Singer and Wolfner Publishing Company focused on child- and youth-literature thus building up a large reading public for their magazines and cheap, popular books. Tutsek, twenty-nine, unmarried, and without financial support gladly took the job in 1894.

Anna Tutsek became the editor-in-chief of Magyar Lányok ['Hungarian Girls'] and due to her new position she could suddenly join the centers of Hungarian literary life. She soon reshaped her occupational identity: from "writer" she turned into a "woman writer," a rather despised profession, but still she integrated into the masculine literary tradition. Besides editing her magazine she started to write a novel series about the adventures of Cilike, a flighty teenage girl. She obviously got the idea from the late nineteenth century German tradition of literature written for female adolescents, the so-called Backfischliteratur (Redmann 2006: 466). In the seven volumes of the series published between the first decade of the twentieth century and the late 1930s which follow Cilike's life from her adolescence to her fifties, she shares many traits with the typical Backfisch heroine: she is talkative and curious, but imprudent and childish. She never outgrows her childishness, even as a grandmother (Mallász 2009: 225). Cilike accepts traditional gender roles, obeys her parents and after getting married willingly submits to her husband and thus becomes a role model for adolescent girls. Although Tutsek herself left Transylvania to get away from the male-centered world of Kolozsvár, in Budapest she was preoccupied with teaching young girls how to fit into the patriarchal society. She did not in the least endorse women's rights in any of her writings, and by the 1930s, partly on account of this representation of conservative values and patriarchal family structure, she had become one of the most favored Hungarian women writers. She was an iconic figure to her lower-middle class and middle class female public, so much so that her fame, primarily through the Cilike novels survived the forty years of politically motivated dismissal following WWII. It was only the republication of her novels in the early 1990s that showed the readers how anachronistic her approach had been already at the time of the creation of the series.

Perhaps it will remain secret forever whether it was the memory of her humiliating impoverished girlhood and young womanhood which had made her abide by the rules in a period when several Hungarian women's associations were working in favor of feminist causes or whether she really believed in this male-centered, anti-feminist ideology. (In 1900, she got married to the journalist Róbert Tábori, her fellow worker at Magyar Lányok, and their marriage lasted until his premature death five years later.) In either case Anna Tutsek's works helped deepen the tradition of women's subordination that has still lasting consequences.

In the 1890s Tutsek might have felt relieved to escape to "the City of Light," as she called Budapest in her memoir, which can perhaps partly explain why she seemed to lack a strong sense of regional identity. By the time her autobiography was published, Budapest, which had been the second largest city of the Austro-Hungarian Monarchy, had declined into the capital of an increasingly monocultural country paralyzed by the consequences of the First World War (Tutsek 1935: 152). Yet, she had no intention of returning to a Transylvania under Romanian sovereignty as for instance Irén Gulácsy, another popular woman writer of the interwar years, did. Nevertheless, Tutsek did not completely renounce her Transylvanian roots as she made her protagonist, Cilike, who was named after the writer's mother, grow up in a small unnamed fictional town in Transylvania. 
Kádár, Judit. "Two Austro-Hungarian Women Writers, Anna Tutsek and Terka Lux, Creating New Urban Identities in Early Twentieth-Century Budapest." Hungarian Cultural Studies. e-Journal of the American Hungarian Educators Association, Volume 8 (2015): http://ahea.pitt.edu DOI: 10.5195/ahea.2015.214

On the whole, it is somewhat surprising that Tutsek, whose writing represented the interests of the Hungarian ruling class, rejected the irredentism of the post-World War I years. In the volume Cilike mint asszony ['Cilike Gets Married,' 1920] whose plot takes place during World War I, the newlywed protagonist agrees without the slightest hesitation to have her house sold (by her parents) and to leave her hometown forever. Her family and the storyteller talk about moving to Budapest and the use of the verb 'felköltözni' ['go up to'] suggests that the writer, whose worldview was represented by the narrator, probably did not consider Transylvania a distinct entity from the Hungarian state, but she refrained from exacerbating revisionist emotions. And indeed, Cilike does not seem to suffer a huge loss: in her new villa in Újpest, a suburb of the capital city, she keeps herself busy with her new home (Tutsek 1989: 180). Cilike did not have a word about Austria-Hungary as her homeland; in the volumes published after the war, the young woman never even mentions that the Austro-Hungarian Monarchy had been dissolved and Transylvania was ceded to Romania. Cilike, just like her creator, abided by the rules of conduct set out for women: she abstained from politics. Although her autobiography lacks thorough self-reflection, it seems obvious that Anna Tutsek paid a heavy price for the social status she had finally achieved: she intentionally repressed her ethnic identity which went together with the fading-away of her regional identity. In order to survive, she partially abandoned her original occupational identity, and denouncing female identity politics, she surrendered to patriarchal values.

\section{Terka Lux (1873-1938)}

For reasons yet unknown, throughout her career Terka Lux attempted to conceal her true identity. At the start of her career between 1893 and 1896, she used her real name without the prefix of nobility, thereafter she took up a pen name. Her real name, Ida Dancsházi Oláh, simultaneously signified noble blood (Dancsházi) and Romanian ancestors ("Oláh" meaning "Vlach" or "Wallachian" in Hungarian). From the early 1900s when she started working for Pesti Hírlap ['Pest Newspaper'], where she had a regular feuilleton under the title "Hétköznapok" ['Weekdays'], she signed her articles Terka Lux (Schwartz 2008: 206). As Terka is a rustic pet name for Theresia, and the Latin word "lux" stands for "light," or "clarity," this name change suggests not only that she consciously strived to construct a new identity for herself but it may also reflect her commitment to democracy and her engagement in propagating democratic values.

Some of Lux's personal data were published in The Révai Lexicon, a contemporaneous lexicon, which claims that she was born in a little, grape growing town, Szilágysomlyó [Şimleu Silvaniei, Schomlenmarkt] in Partium, a region located to the west of Transylvania. Her father allegedly fought against the Habsburg rule in the Hungarian War of Independence in 1848-1849, and she grew up under the constraints of difficult material circumstances. In 1889, at the age of sixteen she got married to one György Szöllősy, but they soon divorced. In all probability, she started writing articles after her divorce to make a living. In a short résumé written in 1928 for an anthology of Hungarian short stories, Száz magyarok könyvei ['The Book of One Hundred Hungarians'], she proudly claimed that no one knew about her private life, and she "achieved her social status without possessing a title, name, rank and friends, she succeeded only with the sheer force of her talent" [cím, név, rang, barátok nélkül, pusztán tehetsége erejével jutott el a mai polcra] (Kádár 2014: 42). Unlike many of her female contemporaries, for example the poet and critic Sophie Török (the pseudonym of Ilona Tanner), she had no doubts as to whether she had become a full-fledged writer despite being a woman. However, her successful attempt to 
Kádár, Judit. "Two Austro-Hungarian Women Writers, Anna Tutsek and Terka Lux, Creating New Urban Identities in Early Twentieth-Century Budapest." Hungarian Cultural Studies. e-Journal of the American Hungarian Educators Association, Volume 8 (2015): http://ahea.pitt.edu DOI: 10.5195/ahea.2015.214

maintain total secrecy about her private life may be a sign of fearing a threat to her self-esteem; for example, she may have been ashamed to make public either her single status or her civil partnership and her childlessness.

Although she was influenced by Balzac's realism and was at pains to show the dark side of life, Lux hardly ever wrote about the land where she had been brought up and she never recorded her childhood experiences. Though one of her major themes was the loss of identity and traditional values in the modern metropolis, the original surroundings of her protagonists (in most cases immature teenage girls) were schematically presented. Moreover, the roughly sketched small hometowns of her heroines are located in the Great Hungarian Plain [Alföld], while she spent her youth in the hilly parts of Szilágy [Sălaj] county. In some of her short stories the father of the protagonist is an abusive alcoholic; perhaps Terka Lux herself had traumatic experiences of the same type and in order to survive she repressed all memories. As a result, she completely gave up her regional identity and, migrating to the Hungarian capital, she became an urban writer, a lover and hater of the turn-of-the century Budapest. In 1908, she even wrote a novel about a young woman who takes revenge against the exploitation and injustice of mencentered capitalism, titled Budapest.

One of the few exceptions to this obliteration of Lux's childhood surroundings is Fáni és Dani ['Fáni and Dani,' 1905], a novel in which both of the main characters come from the region where the river Tisza originates in the Eastern Carpathian Mountains in Hungary. The main theme of the book is the corruption that pervades the whole society, a phenomenon depicted in two different places. Though he is only twenty-two, due to the political corruption of the Hungarian local officials Dani, of an impoverished gentry family, is made a chief official (föszolgabiró) in an electoral district of his home region populated by Romanian and Hungarian peasants. Fáni, a poor Jewish girl born in the same region, succeeds as a theater student in Budapest, but she is thrown out of the school because of the manipulations of a less talented rival, the mistress of a powerful politician. When, despite all, the nineteen-year-old Fáni gets to be a star, her rival incites anti-Semitism to chase Fáni away. As her plight has been further aggravated by her Jewish origins she gives up her career and returns to her birthplace, where she finds anti-Jewish sentiments milder, "to bury herself in a village where she will graft cacti, crochet lace and each fall when the swallows leave for the south one part of her soul will be torn out" [Eltemetkezni egy faluba, ahol kaktuszokat fog ojtani, csipkét horgol és minden összel ki fog a lelkéböl egy darab szakadni, mikor a fecskék útra kelnek] (Lux 1905: 224).

At the end of the nineteenth century Szilágysomlyó, although it had a Hungarian majority also had a significant Jewish and Romanian population. ${ }^{2}$ Lux was ten years old when an antiJewish riot took place in the town (Barna, Csepeli "Szilágysomlyó"). She became earnestly concerned about anti-Semitism, and racial discrimination in general. It is possible that she may have had Jewish ancestry herself, which might explain her attempts to conceal her true identity. Moreover, in the 1900s, when she settled down in the capital, the hatred of Jews was becoming stronger; many citizens who could not benefit from the rise of industrial capitalism blamed Budapest for being "the city of vice," implicitly accusing the Jewish inhabitants of immorality

${ }^{2}$ In 1890, out of a total population of 4548 there were 1405 Roman Catholics, 893 Greek Catholics and 838 Jews at Szilágysomlyó (Petri IV., 572, web). 
Kádár, Judit. "Two Austro-Hungarian Women Writers, Anna Tutsek and Terka Lux, Creating New Urban Identities in Early Twentieth-Century Budapest." Hungarian Cultural Studies. e-Journal of the American Hungarian Educators Association, Volume 8 (2015): http://ahea.pitt.edu DOI: 10.5195/ahea.2015.214

(Gyáni 2008: 67-68). As a novelist Lux showed the presence of anti-Semitic prejudices in all layers of fin-de-siècle Hungarian society, but she put the most emphasis on Budapest where antiSemitism was hidden behind anti-urbanism (Schwartz 2012: 55). Besides Fáni, the Jewish heroine, Lux's other novels described the life of Christian girls who had to react to urban antiSemitism. Some of these young impoverished protagonists, who live in miserable conditions in dirty tenement rooms like the writer Anna Tutsek or maybe Lux herself, fall in love with Jewish men. If the heroines conform to the expectations of society and turn down the marriage proposal of these men, they invariably become unhappy. For example, in the novel Leányok ['Girls,' 1906], which tells the plight of three girlfriends from the countryside, Janka, Baba, and Juli, the nobly born Janka Kis-Kolozsy of Kaross is punished for her anti-Semitism. Having lost her mother and without financial support, Janka leaves her native town in the Great Plain to earn a living in Budapest. She and her equally talented brother want to attend the Academy of Music there, although both of them seem to be clueless about how to survive in the city: Janka is fluent in three languages but it is beneath her dignity to work as a governess, and Gábor would like to be an heir of an entailed estate, namely, he wants to be a landowner of the old type (Lux 1908: 32). Janka falls in love with a Jewish physician but, bowing to social pressure to marry within their own circle, she marries an old and ugly colonel by whom she has always been repelled.

While Janka displays the traditional gender role of women, the choices of the other two heroines in Leányok show new alternative role models to the "new woman" that appeared in Hungarian society at the turn of the century. Baba, who feels free to satisfy her sexual desires, ends up dying from an illegal abortion, while Juli succeeds in becoming a physician, but lives a solitary life and finally decides to move back to the countryside in the faint hope that she can find a husband. None of these options seem to be appropriate, the one which is described the most viable of them, namely, obtaining a profession and financial freedom goes along with being left alone. As Agatha Schwartz observes, "professional success by itself is presented as a lonely path for the "new woman"” (Schwartz 2012: 116).

Lux's Leányok reveals that her ideas on women's emancipation were somewhat unstable and uncertain - although she was an avowed feminist who published articles in the journal of the Feminist Association (Feministák Egyesülete), A Nö ['The Woman']. Probably influenced by American feminist author Charlotte Perkins Gilman, who believed that only economic independence could bring freedom for women, Lux supported women's right to work and education, but did not regard their right to vote a priority until the outbreak of WW I, and throughout her publishing career she continued to deplore the sexual enlightenment of the young. On the whole, Lux's books seem to suggest that the really satisfying solution to women's new problems must still be marriage, but to be happy, girls must be free to chose their husband and reject prejudices, especially racism.

At the end of the nineteenth century, both Anna Tutsek and Terka Lux gave up their regional identity, a self-denial that was obviously related to the subordination of women in the countryside where the prevailing social norms regarding gender roles prevented them from filling suitable jobs, and they had no choice but to flee. They successfully freed themselves from their subjugated position within society by migrating to Budapest where, having found intellectual jobs, they could form their occupational identity, Tutsek constructing her identity within the patriarchal framework of society while Lux rejected the inferior status of a female writer. In order to get along in the turn-of-the-century Hungarian society that had boosted assimilation, Tutsek abandoned her ethnic identity, while Lux hid hers behind a Latin surname. However, the latter condemned racial discrimination in all its forms, which was a courageous 
Kádár, Judit. "Two Austro-Hungarian Women Writers, Anna Tutsek and Terka Lux, Creating New Urban Identities in Early Twentieth-Century Budapest." Hungarian Cultural Studies. e-Journal of the American Hungarian Educators Association, Volume 8 (2015): http://ahea.pitt.edu DOI: 10.5195/ahea.2015.214

stance in an increasingly discriminatory society. In spite of their literary success, their female identity was vulnerable. Both of them tried to obscure that they had transgressed social norms. As a woman writer, Tutsek did not object to male dominance in society, while Lux supported feminist ideas but inconsistently. In the case of both writers, their female public might have concluded that the safest way to provide security is to get married. In spite of initial difficulties, both of them made a career as a woman writer in a multicultural metropolis and they fared well enough to avoid self-reflection on the personal and cultural loss that had occurred to them. However, the abandonment of their regional and ethnic identity and the inadequate representation of women's rights fostered exclusionist monoculturalism and helped sustain authoritarian attitude in the first half of the twentieth century and later.

\section{Works Cited}

Barna, Ildikó, Csepeli, György, Csősz, László et. al. Társadalmi és etnikai konfliktusok a 19-20. században-Atrocitások, pogromok, tömeggyilkosságok, népirtások ['Social and Ethnic Conflicts in the Nineteenth-Twentieth Centuries - Atrocities, Pogroms, Mass Murders, Genocides']. http://tarsadalominformatika.elte.hu/tananyagok/dka/index.html

Dzsotjanne Krajcsir, Piroska. 1998. "Örmények” ['Armenians']. Nemzeti és etnikai kisebbségek Magyarországon ['National and Ethnic Minorities in Hungary']. Budapest: Auktor. http://www.sulinet.hu/oroksegtar/data/magyarorszagi_nemzetisegek/altalanos/nemzeti_es _etnikai_kisebbsegek_magyarorszagon/pages/009_ormenyek.htm

Gyáni Gábor. 2008. Budapest-túl jón és rosszon. A nagyvárosi múlt mint tapasztalat.

['Budapest—Beyond Good and Evil: The Metropolitan Past as Experience']. Budapest: Nagyvilág.

Hanák, Péter. 1988. A kert és a mühely. Budapest: Gondolat. (English transl. The Garden and the Workshop. Essays on the Cultural History of Vienna and Budapest. With a Preface by Carl E. Schorske. Princeton UP, 2014.)

Kádár, Judit. 2014. Engedelmes lázadók. Magyar irónők és nőideál-konstrukciók a 20. század elsö felében ['Obedient Rebels: Hungarian Women Writers and the Construction of Female Role Models in the First Half of the Twentieth Century']. Pécs: Jelenkor Kiadó.

Lux Terka. 1905. Lenci naplója. Fáni és Dani ['Lenci's Diary. Fáni and Dani']. Budapest: Faragó Zs. . 1906. Leányok ['Girls']. Budapest: Légrády Testvérek.

—. [1913]. Álom. Novellák. ['Dream. Short Stories']. Budapest: Érdekes Újság.

Mallász, Rita. 2009. "Cilike, a népnevelő. Női szerepmodellek és azok identitás-formáló hatása Tutsek Anna Cilike-sorozatában" ['Cilike, the Educator: Female Role Models and Their Effects on Identity Formation']. In Nö, tükör, irás. Értelmezések a 20. század elsö felének női irodalmáról ['Woman, Mirror, Writing. Interpretations on Women's Literature Written in the First half of the Twentieth Century']. Eds. Virág Varga and Zoltán Zsávolya. Budapest: Ráció.

Nemes, Robert. 2005. "The Revolution in Symbols: Hungary in 1848-1849." In Constructing Nationalities in East Central Europe. Eds. Pieter M. Judson and Marsha L. Rozenblit. New York: Berghahn Books.

Petri, Mór. 1901-1904. Szilágy vármegye monographiája ['The Monograph of Szilágy County']. Vol. IV. Budapest: Franklin. 
Kádár, Judit. "Two Austro-Hungarian Women Writers, Anna Tutsek and Terka Lux, Creating New Urban Identities in Early Twentieth-Century Budapest." Hungarian Cultural Studies. e-Journal of the American Hungarian

Educators Association, Volume 8 (2015): http://ahea.pitt.edu DOI: 10.5195/ahea.2015.214

Redmann, Jennifer. 2006. "Nostalgia and Optimism in Else Ury's Nesthäkchen Books for Young Girls in the Weimar Republic." The German Quarterly 79: 465-483.

Schwartz, Agatha. 2008. Shifting Voices: Feminist Thought and Women's Writing in Fin-de Siècle Austria and Hungary. Montreal: McGill.

—. 2012. "Budapest and Its Heroines in Fin-de-Siècle Hungarian Literature." Hungarian Studies Review 39: 45-74. http://epa.oszk.hu/00000/00010/00046/pdf/EPA00010_hsr_2012_045-074.pdf

Straubhaar, Joseph D. 2008. "Global, Hybrid or Multiple?: Cultural Identities in the Age of Satellite TV and the Internet." Nordicom Review 29: 21-50. http://200.144.189.84/ebooks/arquivos/2170d7dcacee744fa95f3c2dae97ddff.pdf\#page=2 $\underline{1}$

Tutsek, Anna. 1935. Az én utam ['My Way']. Budapest: Singer és Wolfner Irodalmi Intézet. —. 1989. Cilike mint asszony ['Cilike Gets Married']. Budapest: Garabonciás. 